\title{
TURNOVER OF NURSING EMPLOYEES IN A GAUTENG HOSPITAL GROUP
}

\section{Authors:}

Karel Stanz $z^{1}$

Japie Greyling ${ }^{1}$

\section{Affiliations:}

${ }^{1}$ Department of Industrial

Psychology and People

Management University of

Johannesburg, Johannesburg,

South Africa

\section{Correspondence to:}

Karel Stanz

email:

karel.stanz@up.ac.za

Postal address:

EBW 3-92, Lynnwood

Road, University of

Pretoria, Pretoria 0002,

South Africa

\section{Keywords:}

organisational behaviour; voluntary turnover; hospital management; causes of turnover; South African hospitals

\section{Dates:}

Received: 12 Aug. 2009

Accepted: 07 July 2010

Published: 04 Nov. 2010

How to cite this article: Stanz, K., \& Greyling, J. (2010). Turnover of nursing employees in a Gauteng hospital group. SA Journal of Industrial Psychology/SA Tydskrif vir Bedryfsielkunde, 36(1), Art. \#850, 11 pages.

DOI: 10.4102/sajip.v36i1.850

This article is available at:

http://www.sajip.co.za
(C) 2010. The Authors.

Licensee: OpenJournals Publishing. This work is licensed under the Creative Commons Attribution License.

\begin{abstract}
Orientation: The South African nursing profession is in a crisis as professional nurses leave the country in search of lucrative work overseas.

Research purpose: The purpose of this study was to investigate individual determinants of voluntary turnover to identify a risk-group profile.

Motivation for the study: Nursing employers should have a clearer understanding of the dynamics around nurses' turnover behaviour and embark on strategies to retain their talent.

Research design, approach and method: A survey measuring voluntary turnover was conducted among 262 professional and assistant nurses in three selected hospitals in Gauteng province using the McCarthy, Tyrrell and Cronin (2002) instrument. Pearson's chi square with Yates's continuity correction tested the relationship among the variables presented in a contingency table, in other
\end{abstract} words the risk group and each of the individual determinants.

Main findings: Discontent with salaries was the major determinant of the nurses' resignation. Organisational causes were nursing practices, the work environment, physical-emotional costs and employment opportunities after resignation.

Practical/managerial implications: Hospital management could indeed establish a good rapport with nursing staff while facilitating respectful and ethical conduct by doctors towards nursing staff. Putting into place effective labour practices and business strategies could improve job satisfaction in the workplace.

Contribution/value-add: This study contributed to a greater understanding of the personal and organisational determinants of the turnover of nurses in South African hospitals.

\section{INTRODUCTION}

The South African nursing profession is in a crisis as scores of professionals seek alternative employment or opt to leave the country in search of lucrative work overseas. This exodus will have a catastrophic effect on the delivery of health care over the next decade (Thom, 2003). The core of the intensifying problem is that a direct currency-to-currency comparison between the remuneration of nursing employees in South Africa and developed countries indicates that nurses who earned an average of R5000 a month in South Africa are earning, for example, about R27 000 in Saudi Arabia (Govender, 2002). The allure of the British pound and the US dollar has also seen international recruitment agents flourish in South Africa (Pela, 2003). Mngomezulu in IRIN (2004) stated that more than 300 specialist nurses leave South Africa every month.

According to the Human Sciences Research Council, it is estimated that South Africa will have a shortage of 19000 nurses within 8 years (Olivier, 2003). According to the South African Nursing Council (SANC), there are approximately 93000 registered nurses in South Africa, of whom only about 3800 have an intensive-care qualification. Of this pool, $20 \%$ are either non-practicing or in non-related employment. A private-hospital group reports $20 \%-30 \%$ of positions as vacant and that its specialised units are only $50 \%$ filled (Smit, 2003). It is important to understand that external factors, such as well-paid job opportunities, are not the only driving force behind the turnover. Nursing employees should also understand that, due to financial constraints, it is very often impossible to adapt to external forces such as remuneration offerings from national and international competitors to retain talent.

The consequences of this situation manifest in various areas and are a cause of concern. First of all, South Africa is left with junior nurses who still need training and guidance (Mngomezulu in IRIN, 2004). Furthermore, this situation creates enormous problems of mental and physical fatigue as some nurses work $18-22$ hours per day. This leads to wrong decision-making, the SANC confirming that there has been a substantial increase in medico-legal incidents (Smit, 2003). The Faculty of Health Sciences at the University of Cape Town has also reported increased pressure on remaining staff brought about by critical staff shortages. Other causes of turnover are little scope for further training, a lack of respect and acknowledgement from other medical professions as well as poor working conditions in hospitals (Thom, 2003). Employers, for example, are often unwilling to give nurses time off for training due to severe staff shortages (Smetherham \& Laurance, 2003). It is also apparent from various reports that working conditions are appalling (Smit, 2003). Indeed, the most prominent union of South African nurses, The Democratic Nursing Organisation of South Africa (DENOSA), is of the opinion that working conditions should be improved drastically as money cannot compensate for bad working conditions (Smit, 2003). Employee turnover therefore represents a major problem for both the nursing profession and healthcare providers with respect to the ability to care for patients, the quality of the care provided, the loss of 
the continuity of care, the loss of skills and local knowledge, the increased length of stay and the financial costs of replacemen (McCarthy et al., 2002). When considering the current situation, it is clear that employers should identify the dynamics around the turnover behaviour of their nurses and embark on strategies to retain their talent.

\section{Literature review}

Job satisfaction is the most frequently studied psychological characteristic or affective state thought to be related to turnover or turnover intentions (Chiu \& Francesco, 2003; Rosin \& Korabik 1995; Yin \& Yang, 2002). This notion is supported by Lu, While and Barriball (2004), who stated that the recruitment and retention of nurses are two persistent problems associated with job satisfaction. Originally, remuneration, defined as money and its equivalents, as an integral part of job satisfaction, was the main focus of determining turnover (Mobley \& Griffeth, 1979; Price, 2001). However, research in the international arena indicates that there is much more to employee turnover than pay. Other factors that lead to turnover in nursing include long working hours, heavy workloads, employee shortages, an inability to finish shifts on time, overtime and unpaid overtime, vacancies left unfilled, a lack of funds for training and development as well as a culture of nurses using their own time and money to undergo training (Newman, Maylor \& Chansarkar, 2002).

South Korean researchers Lee, Song, Cho, Lee and Daly (2003) conducted a study on 181 nurses, which showed that the most frequently mentioned reasons for nurses' intention to leave their jobs were work overload, rotating shifts (staff organisation) and interpersonal conflict, while Cavanagh (1990) found that 232 US hospital nurses' turnover could be predicted by promotion, salary and communication. Cavanagh and Coffin (1992) reported job satisfaction and participation at work to be important variables in the turnover process. They found three variables significantly related to the intent to stay, namely job satisfaction, pay and opportunity ('advancement'). An additional demographic factor, that of kinship responsibilities, also predicts nurses' turnover. The meta-analysis (129 studies relating to turnover from 1978 to 1998) by Yin and Yang (2002) furthermore found that the strongest individual and organisational factors related to nurse turnover were job satisfaction, autonomy, advancement opportunity, job stress, pay, group cohesion ('coworkers'), marital status and educational level.

Lu, Lin, Wu, Hsieh and Chang (2002) found, in a sample of 2197 Taiwanese nurses, that $38.4 \%$ of the nurses could be classified as having the intention to leave the profession because of a lack of job satisfaction. Stolte and Myers (1995) reported that salary and benefits, working hours, personal achievement, staff relationships and patient contact were among the most frequently mentioned reasons for female maternity nurses to leave. Iverson (1999) found that autonomy significantly explained nurses' decision to resign; various other job-related variables, such as role conflict, co-workers and supervisory support, did not significantly explain the variance in turnover intentions. This result is consistent with various other findings that the autonomy of nurses is one of the most important determinants of job satisfaction and, ultimately, of turnover intentions (Currivan, 1999; Yin \& Yang, 2002). Seo, Ko and Price (2004) suggested that the level of job autonomy and job growth of hospital nurses is further restricted by physicians, who have the power to decide the scope of nurses' work Indeed, experience in the USA shows that nurses who receive more recognition and autonomy are more inclined to stay with their employers (Liebenberg, 2003). Dissatisfaction with promotion and training opportunities has a stronger impact on nurses' satisfaction than workload or pay (Shields \& Ward, 2001). Retention policies, which focus heavily on improving pay for nurses, therefore have only limited success unless they are accompanied by improved promotion and training opportunities.
Although this list is by no means comprehensive of all previous research, it is clear that compensation (salary, pay and fringe benefits), advancement (promotion opportunities), autonomy and relationships with co-workers are most often mentioned as factors that influence nurses' decision to stay or leave their job. Promotion opportunities go hand in hand with the level of compensation and it therefore seems that compensation is the most prominent factor in nurses' employment turnover.

\section{Staff or employee turnover}

Mobley (1981), who is regarded by many as the father of research about employee turnover, defined turnover as the 'cessation of membership in an organization by an individual who received monetary compensation from the organization' The single most reliable predictor of actual turnover is an employee's behavioural intention to stay or to leave an organisation and is the final cognitive step in the decision-making process (Mobley \& Griffeth, 1979). According to Mano-Negrin (2001), staying or leaving an organisation is an integral part of an employee's behavioural decision set and presents a continuous challenge to human-resource managers and scholars.

Turnover is also conceptualised in terms of voluntary and involuntary turnover, which are sometimes termed 'avoidable' and 'unavoidable' turnover, respectively (Price, 1977; Price, 2001). Voluntary turnover (quitting) is defined as turnover initiated by the employee (which therefore does not include firings, lay-offs, within-agency promotions or death) (Razza, 1993). Zeffane (1994) claimed that among those factors leading to voluntary employee turnover are external factors (such as the labour market, economic conditions, legislation and the political situation), institutional factors (such as physical working conditions, pay, job skills and supervision), employee personal characteristics (such as intelligence and aptitude, personal history, sex, age and tenure) and employee reactions to their jobs (such as job satisfaction, job involvement and job expectation Figure 1).

According to Jacobs (2005), it is important that turnover models should consist of various predictors. The reasoning behind this is that turnover cognitions that often lead to turnover are naturally complex due to the aspects of human nature attached to it. It was therefore decided to focus more holistically on the problem by including various individual and organisational determinants as well as outside opportunities to a certain extent, such as work abroad, a career break and even employment outside nursing. The rationale for this decision was also based on findings by Jacobs (2005) and by Jacobs and Roodt $(2006 ; 2008)$, who reported that the turnover model developed in their studies focused only on internal dimensions and excluded external forces such as job opportunities, which, theoretically, are described as important

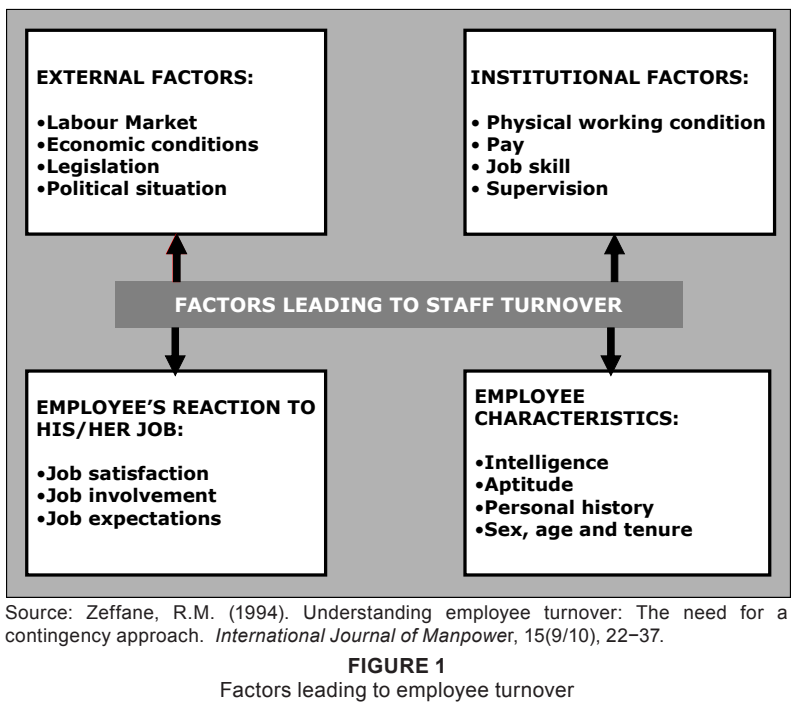

Factors leading to employee turnover 


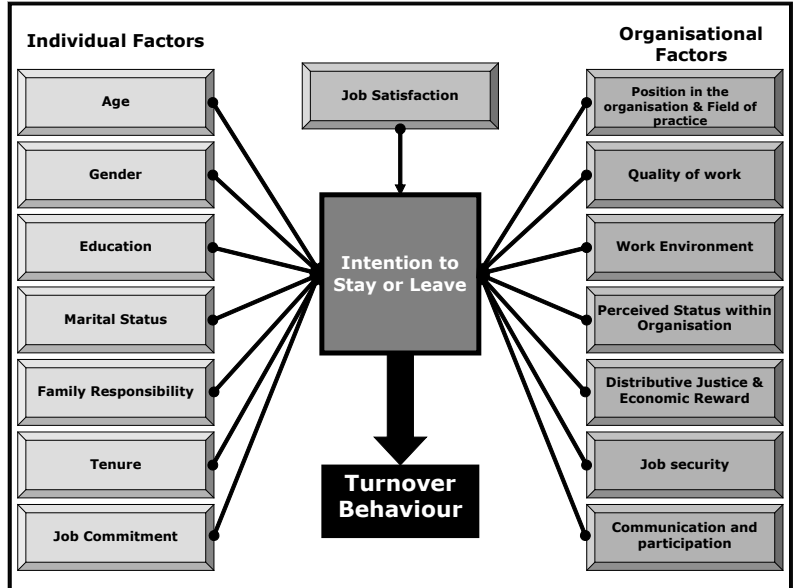

McCarthy, G., Tyrrell, M.P., \& Cronin, C. (2002). National study of turnover in nursing and midwifery, Department of Nursing Studies, University College Cork - National University of Ireland Submitted to the Depatment of Health and Children for the Study of the Nursing and Midwifery Resource, report no. 1, July 2002.

FIGURE 2

Conceptual framework of the turnover determinants of McCarthy

in turnover cognitions. 'Job opportunity' refers to the degree of job availability outside an organisation (Seo et al., 2004).

Contradicting notions do exist, as Lee, Mitchell, Wise and Fireman (1996) reported that $45 \%$ of departing nurses abandon their present employment without a job offer in hand. This notion is supported by Mano-Negrin and Tzafrir (2004), in that the turnover intention of hospital personnel is not preceded by a job search and does not significantly impact on turnover behaviour. Empirical evidence on the extent that outside opportunities contribute to voluntary turnover is lacking.

The current research is based on the conceptual framework of turnover determinants by McCarthy et al. (2002). According to these authors, the determinants of turnover can be classified into mainly individual and organisational factors. This is theoretically supported by Campion (1991), who reported that the decision of an employee to leave an organisation is a product or function of both individual and organisational determinants. According to McCarthy et al., individual factors refer to, for example, age, gender and educational level, while organisational factors refer to, for example, the work environment, job security and perceived status within a hospital. Figure 2 provides a conceptual framework of the determinants related to employee turnover as used in this research.

\section{Research objectives}

The problem in South Africa centres on two issues, namely the inability of the nursing profession to attract new members and the high rates of turnover among staff (Van Niekerk \& Sanders, 1997). The aim of this research was therefore to investigate voluntary turnover among nursing employees in a sample of hospitals in Gauteng and to determine the reasons for employee turnover among nursing employees in the South African context.

The problem statement of the research was defined as follows: What are the determinants of potential voluntary employee turnover among nursing employees? The principal problem was further analysed in terms of the following sub-problems: What are the individual determinants that will lead to potential employee turnover and what are the organisational determinants that will lead to potential employee turnover among nursing employees? The aim of the sub-problems was to determine the differences between high and low-risk groups.

Given the indicated implications of employee turnover, the results of this study can benefit both the employer and the employee. Business leaders, however, seem to disregard the holistic view of the reasons for employee turnover, a simplistic assumption in South Africa being that it is only pay that causes employee turnover. This is why remuneration has been investigated in so many studies.

If the determinants of employee turnover can be accurately identified, however, health-care organisations in South Africa could make significant savings if these can be transformed into retention strategies. Labour turnover is an inevitable phenomenon in an organisation's life cycle, involving redundant monetary and non-monetary costs alike, particularly when efficient and experienced workers leave voluntarily with substantial amounts of investments in their human capital (e.g schooling, experience, skills, etc.) (Weisberg, 1994). In the research design that follows, the sampling strategy and datacollection process are thoroughly explained and the stages of the analysis are discussed.

\section{RESEARCH DESIGN}

\section{Research approach}

The research undertaken was exploratory and quantitative in nature. Primary data were collected with a survey instrument to assess the turnover propensity of staff. Descriptive and inferential statistical techniques were used to analyse the data obtained.

\section{Research method}

\section{Sampling}

According to Mouton (1996), it is important to distinguish between a target population and a sampling frame. A target population is the population to which one wishes to generalise, while a sampling frame (a unit of analysis) is the set of cases from which a sample will actually be selected. The target population in this study was represented by 16 private hospitals in Gauteng, traditionally divided into large (A hospitals), medium ( $\mathrm{B}$ hospitals) and small (C hospitals) hospitals. The next step was to decide on the actual composition of the unit of analysis. Three hospitals in Gauteng were randomly selected to be included in the research: Hospital A (A-sized hospital); Hospital B (B-sized hospital) and Hospital C (C-sized hospital). A total of 464 questionnaires was then sent out to the fulltime employees. The sample excluded part-time and agency employees but included nursing assistants with the highest qualification of Grade 12 (i.e. not professional nurses). A total of 262 questionnaires was completed and returned, giving a response rate of $56.47 \%$. The response rate for the three hospitals is shown in Table 1.

The majority of the employees who participated in the research were female $(96.4 \%)$, while approximately $38.6 \%$ of the employees were in the age bracket of $41-50$ years. Full biographical details are provided in Table 2 .

\section{Measuring instrument}

A self-report questionnaire consisting of 31 items was designed to collect data on turnover rates and to research the underlying reasons for turnover. With the permission of the authors, the McCarthy et al. measuring instrument utilised in the National

TABLE 1

Response rate from individual hospitals

\begin{tabular}{llcc}
\hline \multirow{4}{*}{ Hospital } & \multicolumn{2}{c}{ Questionnaires } & \\
\cline { 2 - 3 } Hospital A & 308 & Returned & Response rate \\
Hospital B & 89 & 157 & $50.97 \%$ \\
Hospital C & 67 & 58 & $65.17 \%$ \\
\hline Total & $\mathbf{4 6 4}$ & 47 & $70.15 \%$ \\
\hline
\end{tabular}


TABLE 2(a)

Biographical data of the sample

\begin{tabular}{|c|c|c|c|}
\hline Item & Biographical data & Count & $\%$ \\
\hline \multirow[t]{4}{*}{ Age } & 30 or younger & 30 & 11.8 \\
\hline & $31-40$ years & 82 & 32.3 \\
\hline & $41-50$ years & 98 & 38.6 \\
\hline & Older than 51 & 44 & 17.3 \\
\hline \multirow[t]{2}{*}{ Gender } & Male & 9 & 3.6 \\
\hline & Female & 244 & 96.4 \\
\hline \multirow[t]{2}{*}{ Marital Status } & Married & 150 & 56.8 \\
\hline & Not married & 114 & 43.2 \\
\hline \multirow{4}{*}{$\begin{array}{l}\text { Children younger than } 18 \\
\text { living with employee }\end{array}$} & None & 57 & 23.8 \\
\hline & One & 69 & 28.8 \\
\hline & Two & 77 & 32.1 \\
\hline & Three or more & 37 & 15.4 \\
\hline \multirow{3}{*}{$\begin{array}{l}\text { Main responsibilty for child } \\
\text { rearing }\end{array}$} & Self & 143 & 58.4 \\
\hline & Not youself & 36 & 14.7 \\
\hline & Not applicable & 66 & 26.9 \\
\hline
\end{tabular}

Number of people

dependent on

earnings of employee

\begin{tabular}{lll} 
None & 30 & 12.1 \\
One & 60 & 24.3 \\
Two & 38 & 15.4 \\
Three & 55 & 22.3 \\
Four of more & 64 & 25.9 \\
& & \\
One & 103 & 41.4 \\
Two or more & 146 & 58.6 \\
& & \\
Self & 152 & 57.6 \\
Not self & 112 & 42.4 \\
& & \\
Matric only & 51 & 21.3 \\
College diploma(s) only & 84 & 35.1 \\
Degree or further qualification(s) & 104 & 43.5 \\
\hline
\end{tabular}

Study of Turnover in Nursing and Midwifery undertaken in Ireland (McCarthy et al., 2002) was adapted for South African circumstances. The questionnaire was divided into the following sections:

- background information (questions 1 - 8)

- educational background information (questions 9-15)

- the nursing employees' working arrangements (questions $16-22)$

- the nursing employees' perception of their physical work environment, of nursing practices, of their benefits, of their promotional opportunities, of information sharing and of participation in decision-making (questions $23-26$ )

- voluntary employee turnover and the reasons why nursing employees decided to leave the hospital group's employment (questions 27 - 31).

\section{Data collection}

A pilot study consisting of a total of 15 questionnaires was undertaken at a fourth hospital (Hospital D) with the approval of that hospital's management. The purpose of the pilot study was twofold: (1) to determine whether the research procedure was adequate and (1) to gather empirical support for the layout, the user-friendliness and the face and content validity of the measuring instrument. After the interpretation of the results of the pilot study, the research process and measuring instrument were adapted to enable the researcher to collect
TABLE 2(b)

Biographical data of the sample

\begin{tabular}{|c|c|c|c|c|}
\hline Item & \multicolumn{2}{|l|}{ Category } & Count & $\%$ \\
\hline \multirow{3}{*}{$\begin{array}{l}\text { Which nursing } \\
\text { registration do you hold? }\end{array}$} & \multicolumn{2}{|c|}{ Registered Nurse } & 172 & 70.5 \\
\hline & \multicolumn{2}{|l|}{ Enrolled Nurse } & 35 & 14.3 \\
\hline & \multicolumn{2}{|c|}{ Enrolled Nursing Assistant } & 37 & 15.2 \\
\hline \multirow[t]{8}{*}{ Years as registered nurse } & \multicolumn{2}{|l|}{$0-5$} & 13 & 5.6 \\
\hline & \multicolumn{2}{|l|}{$6-10$} & 28 & 12.1 \\
\hline & \multicolumn{2}{|l|}{$11-15$} & 38 & 16.5 \\
\hline & \multicolumn{2}{|l|}{$16-20$} & 48 & 20.8 \\
\hline & \multicolumn{2}{|l|}{$21-25$} & 33 & 14.3 \\
\hline & \multicolumn{2}{|l|}{$26-30$} & 41 & 17.7 \\
\hline & \multicolumn{2}{|l|}{$31-35$} & 19 & 8.2 \\
\hline & \multicolumn{2}{|l|}{$36-40$} & 11 & 4.8 \\
\hline \multirow[t]{4}{*}{ Tenure: Years at hospital } & \multicolumn{2}{|l|}{ Up to 2 years } & 79 & 31.9 \\
\hline & \multicolumn{2}{|l|}{$2-5$ years } & 66 & 26.6 \\
\hline & \multicolumn{2}{|c|}{ More than 5 years } & 103 & 41.5 \\
\hline & \multicolumn{2}{|l|}{ Total } & 248 & 100 \\
\hline \multirow[t]{4}{*}{ Tenure: Years in position } & \multicolumn{2}{|l|}{ Up to 2 years } & 57 & 22.5 \\
\hline & \multicolumn{2}{|l|}{$2-5$ years } & 68 & 26.9 \\
\hline & \multicolumn{2}{|l|}{$5-10$ years } & 45 & 17.8 \\
\hline & \multicolumn{2}{|c|}{ More than 10 years } & 83 & 32.8 \\
\hline \multirow{3}{*}{$\begin{array}{l}\text { How long (on average) } \\
\text { does it take you to travel } \\
\text { to work each day? }\end{array}$} & \multicolumn{2}{|c|}{ Less than 30 minutes } & 166 & 65.6 \\
\hline & \multicolumn{2}{|c|}{ More than 30 minutes } & 87 & 34.4 \\
\hline & Minimum & Maximum & Mean & $S D$ \\
\hline Paid overtime & 0 & 80 & 15.95 & 16.141 \\
\hline Unpaid overtime & 0 & 74 & 1.62 & 6.98 \\
\hline
\end{tabular}

$N$, number of items; $S D$, standard deviation

data effectively, based on the literature review. Permission was obtained from all the hospital managers and nursing managers at the three hospitals where the research was undertaken prior to the distribution of the measuring instrument. All the ethical requirements regarding data collection, confidentiality and plans not to disrupt internal hospital arrangements were met.

\section{RESULTS}

\section{Main reasons why the nurses would leave their employer}

The nurses first had to indicate only the main reason why they would leave their employer. Out of the 233 respondents, $54(23.18 \%)$ indicated that the main reason would be because of discontent with their salary, $36(15.45 \%)$ indicated that they would leave because of retirement and 35 (15.02\%) indicated that they would leave because they wanted to work abroad. Regarding unhappiness and discontent with their current jobs, $22(9.44 \%)$ of the respondents indicated that this would be their main reason for leaving. Interestingly, only $5(2.1 \%)$ of the respondents indicated that they would leave to pursue further studies outside nursing, while 7 (3\%) of the respondents indicated that they would leave to pursue other employment in nursing outside the hospital group. Figure 3 shows the remaining reasons why the employees would leave the services of the hospital group.

\section{Factors why the nurses would leave their employer}

The respondents were then presented with a list of 24 factors. They were asked why they would leave the hospital group and to indicate the most important and the second-most important factors. From the 208 respondents, 89 (Group 1) $(42.79 \%)$ indicated that poor pay and benefits would be the most 


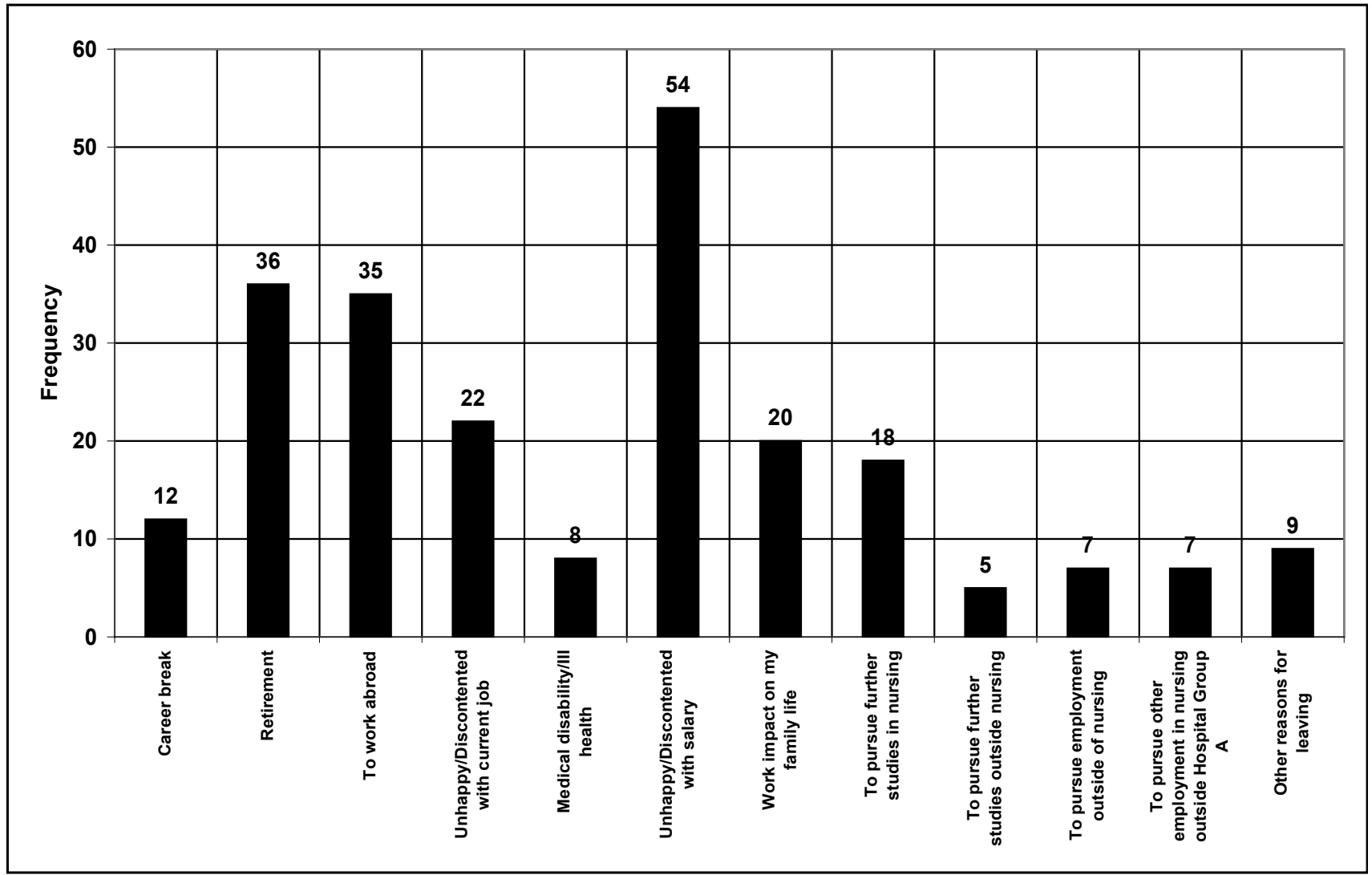

FIGURE 3

Reasons why employees would leave the services of the hospital group

TABLE 3

Most important factors for which employees would leave the services of the hospital group

\begin{tabular}{|c|c|c|c|c|}
\hline \multirow[b]{3}{*}{ Item } & \multicolumn{4}{|c|}{ Factor importance } \\
\hline & \multicolumn{2}{|c|}{ Group 1 - Most } & \multicolumn{2}{|c|}{ Group 2 - Second-most } \\
\hline & Count & $\%$ & Count & $\%$ \\
\hline Poor pay and benefits & 89 & 42.8 & 27 & 13.4 \\
\hline Quality of management & 17 & 8.2 & 11 & 5.5 \\
\hline Work-related stress & 15 & 7.2 & 16 & 8.0 \\
\hline Personal/Family matters & 14 & 6.7 & 5 & 2.5 \\
\hline Poor promotion prospects & 12 & 5.8 & 5 & 2.5 \\
\hline Not enough job satisfaction & 11 & 5.3 & 14 & 7.0 \\
\hline No praise for jobs well done & 9 & 4.3 & 14 & 7.0 \\
\hline Poor working conditions & 7 & 3.4 & 15 & 7.5 \\
\hline Poor training opportunities & 5 & 2.4 & 9 & 4.5 \\
\hline Not enough career opportunities & 4 & 1.9 & 6 & 3.0 \\
\hline Not feeling valued by organisation & 4 & 1.9 & 12 & 6.0 \\
\hline Hazardous nature of work & 3 & 1.4 & 5 & 2.5 \\
\hline Lack of patient contact & 3 & 1.4 & 3 & 1.5 \\
\hline Difficulty in getting transfer & 3 & 1.4 & 1 & 0.5 \\
\hline Poor respect and acknowledgement & 2 & 1.0 & 9 & 4.5 \\
\hline External work pressures & 2 & 1.0 & 3 & 1.5 \\
\hline Unexpected outside job offer & 2 & 1.0 & 20 & 10 \\
\hline Too much work & 2 & 1.0 & 14 & 7.0 \\
\hline No careers for part-timers & 1 & 0.5 & 2 & 1.0 \\
\hline Not enough responsibility & 1 & 0.5 & - & - \\
\hline Dull and routine work & 1 & 0.5 & 2 & 1.0 \\
\hline Unfair system of promotion & 1 & 0.5 & 2 & 1.0 \\
\hline Job not what is expected & - & - & 4 & 2.0 \\
\hline Lack of challenges & - & - & 2 & 1.0 \\
\hline
\end{tabular}

important factor in their decision to leave, while a further 27 from the 201 respondents (Group 2) (13.43\%) indicated that poor pay and benefits would be the second-most important factor, representing $56.22 \%$ of all the possible responses. The quality of management was a factor that was viewed by $17(8.2 \%)$ of the respondents as an important determinant in their decision to leave. Other reasons that figured prominently were workrelated stress $(15 ; 7.2 \%)$ and personal and family matters (14; $6.7 \%$ ). The results are shown in Table 3.

An important part of the research was to identify the nursing employees that might well leave their employment with the 
TABLE 4

Formation of risk groups

\begin{tabular}{lccc}
\hline Risk group & Frequency & $\%$ & $\begin{array}{c}\text { Cumulative } \\
\%\end{array}$ \\
\hline High & 98 & 37.1 & 37.1 \\
Medium & 70 & 26.5 & 63.6 \\
Low & 96 & 36.4 & 100 \\
Total & 264 & 100 & - \\
\hline
\end{tabular}

TABLE 5

Group descriptive statistics

\begin{tabular}{|c|c|c|c|}
\hline \multirow[b]{2}{*}{$\begin{array}{l}\text { Personal/Individual } \\
\text { determinant }\end{array}$} & \multicolumn{3}{|c|}{ Pearson's chi square } \\
\hline & Value & $d f$ & $\begin{array}{c}\text { Asymp. Sig. } \\
\text { (2-sided) } p \text {-value }\end{array}$ \\
\hline Age & 5.576 & 3 & 0.134 \\
\hline Gender & 2.167 & 1 & 0.141 \\
\hline Marital status & 0.097 & 1 & 0.756 \\
\hline $\begin{array}{l}\text { Children younger than } 18 \text { living } \\
\text { with employee }\end{array}$ & 3.017 & 3 & 0.389 \\
\hline $\begin{array}{l}\text { Main responsibility for child } \\
\text { rearing }\end{array}$ & 0.559 & 2 & 0.756 \\
\hline $\begin{array}{l}\text { Number of people dependent } \\
\text { on earnings of employee }\end{array}$ & 4.455 & 4 & 0.348 \\
\hline $\begin{array}{l}\text { Number of wage-earners in } \\
\text { household }\end{array}$ & 1.878 & 1 & 0.171 \\
\hline Main wage-earner in household & 4.098 & 1 & 0.056 \\
\hline Educational qualification & 0.725 & 2 & 0.696 \\
\hline Tenure: Years at hospital & 0.01 & 2 & 0.995 \\
\hline Tenure: Years in position & 5.042 & 3 & 0.169 \\
\hline Daily travel time to work & 0.136 & 1 & 0.712 \\
\hline $\begin{array}{l}\text { Number of years registered } \\
\text { with SANC }\end{array}$ & 0.888 & 2 & 0.641 \\
\hline Paid overtime & 1.456 & 3 & 0.693 \\
\hline Unpaid overtime & 0.003 & 1 & 0.959 \\
\hline
\end{tabular}

$d f$, degree of freedom; Sig., significance

hospital group. The respondents who indicated that they might leave their employment were asked to choose from a list of 25 reasons why they would do so. From their responses, it was possible to identify three risk groups. The first, labelled the high-risk group, selected nine or more reasons why they might leave. The second, labelled the moderate-risk group, selected between four and eight reasons why they might leave. The third, labelled the low-risk group, selected three or fewer reasons why they might leave. Table 4 indicates the three risk groups that were identified. For the purpose of this research, the medium-risk group was not used to distinguish the nursing employees who might leave the services of the hospital group. This was done to maximise the differences between the groups that were compared.

\section{Personal or individual determinants of employee turnover}

Pearson's chi square was used in conjunction with Yates's continuity correction to test whether a relationship existed between the risk group, and each of the personal or individual determinants. Use of the chi-squared distribution to interpret Pearson's chi square could introduce error of interpretation. Yates's correction, however, reduces the chi-square value and increases its $p$-value; it is therefore used to test for independence in a contingency table. The results, degrees of freedom and $p$-values are presented in Table 5 and are then discussed.

In each instance, the risk groups proved to be independent of the following biographical factors:

- age

- gender

- marital status

- 'Children younger than 18 years of age living with the respondent'

- 'Main responsibility for child rearing'
TABLE 6

Cross-tabulation for variable 'Main wage earner in household'

\begin{tabular}{|c|c|c|c|c|c|c|}
\hline \multirow[b]{2}{*}{ Risk group } & \multicolumn{2}{|c|}{ Main wage earner } & \multicolumn{2}{|c|}{ Not main wage earner } & \multicolumn{2}{|c|}{ Total } \\
\hline & $N$ & $\%$ & $N$ & $\%$ & $N$ & $\%$ \\
\hline High & 66 & 67.3 & 32 & 32.7 & 98 & 100 \\
\hline Low & 51 & 53.1 & 45 & 46.9 & 96 & 100 \\
\hline Total & 117 & 60.3 & 77 & 39.7 & 194 & 100 \\
\hline
\end{tabular}

- 'Number of people dependent on earnings of employee'

- 'Number of wage earners in household'

- 'Main wage earner in household'.

None played a significant role in the respondents' decision to leave or stay with their organisation, although there seemed to be an indication of dependency in respect of 'Main wage earner in household' (see Table 6 for the statistical analysis in support of this statement). This could be confirmed by increasing the sample in future research studies. The cross-tabulation in Table 6 indicates the results for this specific variable.

For 'Educational qualification' with its three categories, a $p$-value of 0.696 was obtained. The $p$-value was therefore greater than 0.05 , which supported the null hypothesis, in other words the risk groups were independent of 'Educational qualification' and educational qualifications played no significant role in the respondents' decision to leave or stay with their organisation. 'Tenure: years at hospital', 'Tenure: years in position', 'Daily travel time to work' and 'Number of years registered with the SANC' indicated a chi square of 0.641 , which supported the null hypothesis. The $p$-value for 'Paid overtime' was 0.693 , which supported the null hypothesis, in other words the risk groups were independent of 'Paid overtime' and it played no significan role in the respondents' decision to leave their organisation. The Pearson's chi-square value for 'Unpaid overtime' equalled 0.959 - greater than 0.05 - which supported the null hypothesis, in other words the risk groups were independent of 'Unpaid overtime' and it played no significant role in the respondents' decision to leave their organisation.

Risk-group statistics

\begin{tabular}{|c|c|c|c|c|}
\hline $\begin{array}{l}\text { Attitude towards organisational } \\
\text { determinants }\end{array}$ & Risk group & $N$ & Mean & $S D$ \\
\hline \multirow[t]{2}{*}{ Nursing Practices } & High & 98 & 1.76 & 0.488 \\
\hline & Low & 82 & 1.72 & 0.401 \\
\hline \multirow[t]{2}{*}{ Work environment } & High & 98 & 2.1 & 0.554 \\
\hline & Low & 83 & 1.87 & 0.473 \\
\hline \multirow[t]{2}{*}{ Benefits } & High & 98 & 2.63 & 0.684 \\
\hline & Low & 83 & 2.44 & 0.655 \\
\hline \multirow[t]{2}{*}{ Physical-emotional costs } & High & 95 & 1.89 & 0.759 \\
\hline & Low & 81 & 2.33 & 0.657 \\
\hline \multirow[t]{2}{*}{ Opportunities available on resignation } & High & 91 & 2.05 & 0.606 \\
\hline & Low & 75 & 2.46 & 0.699 \\
\hline \multirow[t]{2}{*}{ Job characteristics } & High & 94 & 2.93 & 0.594 \\
\hline & Low & 78 & 3.24 & 0.534 \\
\hline \multirow[t]{2}{*}{ Promotional opportunities } & High & 85 & 2.85 & 0.945 \\
\hline & Low & 70 & 2.41 & 0.732 \\
\hline \multirow[t]{2}{*}{ How well informed employee is } & High & 93 & 1.68 & 0.728 \\
\hline & Low & 73 & 1.46 & 0.586 \\
\hline How involved employee is in & High & 92 & 3.11 & 1.180 \\
\hline decision-making & Low & 73 & 3.52 & 0.968 \\
\hline
\end{tabular}

$N$, number of items; $S D$, standard diviation 


\section{Organisational determinants of employee turnover}

Before a $t$-test was conducted, Levene's statistic was calculated to ensure comparable variances between the groups. Levene's statistic tests the null hypothesis that the error variances are equal across groups. If the value for the Levene test is not significant $(p>0.05)$, then the $t$-test that assumes equal variances for both groups is used but, if the Levene test is significant $(p<0.05)$, then the $t$-test that does not assume equal variances for both groups is used. In this study, Levene's statistic revealed that there were no significant error variance differences in any of the analyses. The $t$-test results for the equality of means, however, were significant for the following determinants:

- working environment

- physical-emotional costs

- opportunities available on resignation, job characteristics, promotional opportunities, communication (how well informed)

- participation in decision-making.

Table 7 shows the descriptive values of attitude towards the organisational determinants by the high and low-risk groups.

To ascertain the attitudes of the respondents regarding nursing practices, work environment, benefits, physical-emotional costs, opportunities available on resignation, job characteristics, promotional opportunities, how well informed the employee was and how involved the employee was in decision-making, a number of statements were put to the respondents. Based on their responses, a single scale was formed for each of these aspects. To determine whether the risk groups had similar attitudes in terms of the various aspects of organisational determinants, $t$-tests were used. The results of the $t$-tests are shown in Table 8.

Based on the results, the null hypothesis (Ho2: the risk groups had the same mean on organisational determinants) was supported for nursing practices, benefits and promotional opportunity. The null hypothesis was not supported for the following determinants but the alternative hypothesis ( $\mathrm{Ha}$ : the risk groups were dependent on organisational determinants) was: work environment, physical-emotional costs, opportunities available on resignation, job characteristics, how well informed the employee was and how involved the employee was in decision-making.

Regarding nursing practices, the lower the score of a respondent, the more positive the respondent was about nursing practices; the higher the score (close to 4 ), the more negative the respondent was about nursing practices. Because there was no significant difference between the high and low-risk groups, both groups felt the same about nursing practices: in general, both groups were positive about nursing practices in the hospital group, holding similar attitudes.
The variable of work environment indicated the respondents' attitude towards, (1) the support that they received from nursing administration, (2) the goals and concerns that they had as employees and that were shared by hospital administration, (3) autonomy and authority to use their own judgement and make decisions about patient care, (4) whether a spirit of co-operation and teamwork existed in the work environment, (5) how doctors treated them as professionals, (6) whether the respondents' work provided them with educational and learning experiences that would enhance their professional growth and (7) whether they had considerate and responsive supervisors. For the work environment, the lower the score for a respondent, the more positive the respondent was about the work environment; the higher the score (close to 4 ), the more negative the respondent was about the work environment. The findings indicated that the high-risk group differed significantly from the low-risk group in terms of how the respondents felt about their work environment: in particular, the high-risk group had a higher mean score for work environment, implying that these respondents were, on average, more negative towards their work environment than the low-risk group.

The variable of benefits indicated the respondents' attitude towards the following:

- whether they received an acceptable salary

- whether their pay was very good compared to their contribution

- whether they had job security

- whether they could work the hours that they preferred

- whether they believed that their fringe benefits were acceptable.

In terms of interpreting the variable benefits, the lower the score for a respondent, the more positive the respondent was about benefits; the higher the score (close to 4 ), the more negative the respondent was about benefits. In this case, because there was no significant difference between the high and low-risk groups, both groups had the same attitude towards benefits as a predictor of turnover behaviour.

The variable of physical-emotional costs indicated whether the respondents believed that they were overworked, that they had too much to do and that their jobs were stressful. In interpreting the score of physical-emotional costs, the lower the score for a respondent, the more negative the respondent was about physical-emotional costs; the higher the score (close to 4), the more positive the respondent was about physical-emotional costs. The findings indicated that the high-risk group differed significantly from the low-risk group in terms of how the respondents felt about physical-emotional costs, in particular: the high-risk group had a lower mean score for physicalemotional costs, implying that the respondents had, on average, a more negative attitude towards physical-emotional costs than the low-risk group.

The variable of opportunities available on resignation means that the respondents perceived that, on resignation, they would have time to themselves to do the things that they enjoyed, that

TABLE 8

Independence sample test: Organisational determinants

\begin{tabular}{|c|c|c|c|c|}
\hline \multirow[b]{2}{*}{ Attitudes towards organisational determinants } & \multirow{2}{*}{$\begin{array}{l}\text { Equality of variances } \\
\text { based on Levene test }\end{array}$} & \multicolumn{3}{|c|}{$t$-test for equality of means } \\
\hline & & $t$ & $d f$ & $p$ \\
\hline Nursing practice & Can be assumed & 0.612 & 178 & 0.541 \\
\hline Work environment & Can be assumed & 2.904 & 179 & 0.004 \\
\hline Benefits & Cannot be assumed & 1.965 & 179 & 0.051 \\
\hline Physical-emotional costs & Can be assumed & -4.054 & 174 & $<.0005$ \\
\hline Opportunities available on resigning & Can be assumed & -4.029 & 164 & $<.0005$ \\
\hline Promotional opportunities & Can be assumed & 3.134 & 153 & 0.002 \\
\hline Job characteristics & Cannot be assumed & 4.837 & 165.642 & $<.0005$ \\
\hline How well informed & Can be assumed & 2.159 & 164 & 0.032 \\
\hline Participation in decision-making & Can be assumed & -2.406 & 163 & 0.017 \\
\hline
\end{tabular}

$t$, statistical hypothesis value; $d f$, degree of freedom; $p$, probablity value 
they would have more time for their family and that they would be able to meet and be with people of their choice more often Interpreting this variable, the lower the score for a respondent the more negative the respondent was about opportunities available on resignation, whereas higher scores (close to 4 ) indicated that the respondent was more positive about the opportunities. The findings indicated that the high-risk group differed significantly from the low-risk group in terms of how the respondents felt about opportunities available: in particular the high-risk group had a lower mean score for opportunities available on resignation.

The variable of job characteristics indicated the respondents' attitude towards whether they believed that they worked in a unit where they were unfamiliar with the routine and where there was poor communication, whether they felt bored with and restless about their job and whether they believed that their work was affected by poor communication and co-ordination between units or departments. For job characteristics, the higher the score for a respondent, the more positive the respondent was about the job, whereas lower scores (close to 1) indicated more negativity about the job characteristics. The findings indicated that the high-risk group differed significantly from the low-risk group in terms of how the respondents felt: in particular, the high-risk group had a lower mean score for job characteristics, implying that the respondents had, on average, a more negative attitude towards their job. A low score could mean that the respondents worked in a setting where they felt unfamiliar with the routine, equipment and personnel.

The variable of promotional opportunities indicated the respondents' perception of whether there were sufficient opportunities for promotion where they worked. The lower the score for a respondent, the more positive the respondent was about promotional opportunities, whereas higher scores (close to 4 ) demonstrated more negativity. The findings indicated that the high-risk group differed significantly from the low-risk group in terms of how the respondents felt about their opportunities: in particular, the high-risk group had a higher mean score for promotional opportunities, which implied negative attitudes and that the respondents perceived promotional opportunities to be limited at the hospital group.

For the variable of how well informed the employee was, the lower the score for a respondent, the more positive the respondent was about how well informed she or he was by management, while higher scores (close to 4) showed more negativity about how well informed they were. The findings indicated that the high-risk group differed significantly from the low-risk group: in particular, the respondents had a higher mean score for being well informed. Having said that, the respondents in the high-risk group did believe that they were well informed regarding the following:

- what was to be done

- policies and procedures

- the priority of work to be done

- how well the job was to be done

- technical knowledge

- the nature of equipment used

- how they were supposed to do their job.

For the variable of how involved the employee was in decisionmaking, the lower the score for a respondent, the more negative the respondent, while the higher the score (close to 4), the more positive the respondent. The findings indicated that the highrisk group had a significantly higher mean score for involvement in decision-making: the respondents in this risk group therefore believed that they were not involved in decision-making. Decision-making included the following:

- how they did their job

- the sequence of their job activities

- the speed at which they worked

- changing how they did their job.

In conclusion, the intention of the respondents to leave the hospital group was determined by their work environment,
TABLE 9

Group statistics: Job satisfaction

\begin{tabular}{llllll}
\hline & & & & & $S E$ \\
\cline { 5 - 6 } & Risk group & $N$ & Mean & $S D$ & Mean \\
\hline Job satisfaction & High & 94 & 2.26 & 0.736 & 0.076 \\
& Low & 79 & 1.80 & 0.586 & 0.069 \\
\hline
\end{tabular}

$N$, number of items; $S D$, standard deviation; $S E$, standard error

TABLE 10

Independence sample test: Job satisfaction

\begin{tabular}{|c|c|c|c|c|}
\hline \multirow[b]{2}{*}{ Attitudes $^{\dagger}$} & \multirow[t]{2}{*}{ Equality of variances } & \multicolumn{3}{|c|}{$t$-test for equality of means } \\
\hline & & $t$ & $d f$ & $p$ \\
\hline Job satisfaction & cannot be assumed & 4.83 & 165.64 & $<0.000$ \\
\hline
\end{tabular}

physical-emotional costs, opportunities available on resigning, the quality of work, how well informed they were and how involved they were in decision-making.

In Table 9, the group statistics for job satisfaction are indicated. The lower the score obtained, the more positive the respondent was.

Once again, $t$-tests were utilised to compare the means of the two samples. The higher the score (close to 4), the more negative the respondent was about the work environment. By perusing the results in Table 10, it can be seen that the high-risk group differed significantly from the low-risk group in terms of how the respondents felt about job satisfaction and, in particular, that the respondents had a higher mean score for job satisfaction. This implied that they were, on average, more negative towards job satisfaction at their hospitals and hence more likely to terminate their employment at the hospital group.

\section{DISCUSSION}

The objective of this study was to investigate voluntary turnover among nursing employees in a sample of hospitals in Gauteng and to determine the reasons for employee turnover among nursing employees in the South African context. The results that follow, emerged from the study.

\section{Summary of findings}

From the research conducted, it is clear that turnover behaviour is independent of the personal and individual determinants of the respondents. The only variable that indicates a possible relationship is 'Main wage earner in household'. McBey and Karakowsky (2000) reported that main household wage-earners are less likely to exhibit turnover behaviour than individuals who are not the main wage-earners in their households. The rationale for this view is that main household wage-earners have relatively greater responsibility for the financial viability of their households than do secondary wage-earners. For this reason, main wage-earners tend to have less freedom and flexibility to explore job alternatives (they exhibit lower turnover) without incurring substantial penalties (a loss of primary income) for their household units. It is of interest to consider whether this relationship holds in the part-time employment context.

Contradicting the above findings to an extent, Jacobs (2005) found that various biographical factors do, in fact, predict the turnover intentions of nurses (whether positively or negatively), which correlates well with actual turnover. These factors are race, the number of dependants, marital status, tenure, education, age and positional level. In some cases, these variables actually interact (they work together) to predict turnover intentions. Marital status and the number of dependants, however, probably provide similar findings to those above where nurses are the main wage-earners in their households. 
The research demonstrates that the main reason why nursing employees would leave their employment is because they are unhappy or discontent with their salary. This is not surprising, as various other studies have supported this notion (Cavanagh, 1990; Cavanagh \& Coffin, 1992; Stolte \& Myers, 1995; Yin \& Yang, 2002). In recent research, Zondagh (2005) also found that $86 \%$ of the respondents gave poor salaries as the numberone reason why registered nurses resign or leave the nursing profession. This has furthermore been cited as one of the major contributing factors to nurses leaving both the profession and South Africa (Shezi, 2005).

It is clear that several organisational determinants directly influence the nursing employees' intentions to leave the employ of the hospital group. These are their work environment, the physical-emotional costs to them, opportunities available to them on resignation, promotional opportunities, job characteristics, how well informed they are and participation in decision-making.

\section{The work environment includes the following aspects:}

- instrumental communication

- professional latitude and autonomy

- the quality of work life

- relationship with one's supervisor

- routine

- $\quad$ perceived status

- job content.

These aspects are found to be inadequate insofar as the high-risk group is concerned. There is indeed mounting evidence that the adverse working conditions and low satisfaction of nurses are associated with increased nursing turnover (Davidson, Folcarelli, Crawford, Duprat \& Clifford, 1997; Irvine \& Evans, 1995; Leveck \& Jones, 1996). It is the high-risk groups that are more likely to exhibit turnover behaviour if the work environment is not perceived as positive in terms of various outcomes. This is in line with a report by Anderson, Corazzini and McDaniel (2004), who stated that a stable work environment is critical for nursing staff, for whom a significant factor in reducing turnover is the amount of time that they are allowed to spend with each patient. It is therefore suggested that the hospital group investigate strategies to involve nursing employees in making their work environment more employee-friendly to retain staff. The concept of autonomy also needs further mentioning. Although this is only one of the dimensions of the concept of work environment, it is described as a critical factor in nursing turnover intentions (Currivan, 1999; Iverson, 1999; Liebenberg, 2003; Seo et al., 2004; Yin \& Yang, 2002).

Another area of concern from the perspective of the nursing staff is the physical-emotional costs that they experience in their work environments. The respondents in the high-risk group indicate that they feel overworked and have too much to do. They further report that their jobs are stressful and fatiguing. This finding is also in line with various other research (Smit, 2003; Yin \& Yang, 2002).

The high-risk group believes that other opportunities are available on resignation. According to the SANC register, almost $20 \%$ of the country's nurses no longer practise their profession, at least not in a hospital (Smit, 2003).

Insofar as promotional opportunities available to the employees in the hospital group are concerned, the high-risk group feels that there is little chance to get ahead in the employment of the group. The staff also feels that promotions are infrequent within the group and that they occupy dead-end jobs, in other words that there are no growth opportunities for them in the group. This echoes research conducted by Phillips (1990), who contended that the upward mobility of women in occupational settings is loaded with obstacles. Shields and Ward (2001) found that dissatisfaction with promotion and training opportunities has a stronger impact on nurses' satisfaction than either workload or pay.

How well informed the employees are related to whether the respondents believe that they are being kept informed about a number of issues. Townsend, Sundelowitz, Stanz (2007) in their study 'Are they really satisfied?...' found that the essence of dissatisfaction centred around a lack of feedback and followthrough from management. Hargie, Tourish and Wilson (2002) reported that poor communication correlates with lower commitment, reduced productivity, increased absenteeism and higher turnover.

It is found that the respondents in the high-risk group would consider leaving the organisation due to a perception that they are not involved in decision-making, namely how they do their jobs, the sequences of their job activities, the speed at which they work and changing how they do their jobs.

It is clear from the research that there are low levels of job satisfaction with current positions among the respondents. This is consistent with Zondagh (2005), who reported in her research that $92 \%$ of nurses cited general dissatisfaction with nursing as a profession as one of the most possible reasons why registered nurses resign or leave the nursing profession. She further added that only $8 \%$ of respondents believe that general dissatisfaction with nursing as a profession is not a common reason why nurses resign or leave the nursing profession (Zondagh, 2005).

There is consensus among the respondents that dissatisfaction is a big problem in the nursing profession. This notion supports previous research. The overwhelming majority of the respondents are, in fact, of the opinion that this issue is one of the most common reasons why nurses resign or leave nursing. This picture will not change unless most of the issues identified by this study are addressed to improve the general working conditions and poor salaries of nurses. To ignore nurses' job satisfaction will only be detrimental to health care and the managers responsible for it. Private health-care service providers in South Africa are also under pressure to meet their financial targets and, as such, work to reduce costs. This, in many cases, leads to job satisfaction for nursing staff not being very high on their list of priorities. According to Kaplan, Boshoff and Kellerman (1991), South African nurses are shown to have extremely low job satisfaction relative to American nurses and to other professional groups in South Africa.

\section{Management implications}

Managers should realise that there is an urgent need to find financial incentives for nurses. It is also important that nursing salaries be increased relative to the salaries of other health-care professionals, such as medical practitioners, pharmacists and dentists. The perception from nursing staff is that nurses have always been underpaid.

Managers should also realise that their employees are in the people business (they look after patients and their families) and that this can sometimes be taxing on the employees. There are high levels of burnout in the organisation and it seems as if no one is addressing this issue. The emergency, theatre and ICU staff members are the organisation's most valued assets, yet there is no assistance for them in dealing with burnout or post-traumatic stress. The challenge is therefore to develop and introduce an all-inclusive employee-assistance programme that facilitates employee wellness. To retain employees, managers should keep their employees well-informed and involved in corporate decisions. But, most importantly, employees should not be seen simply as cogs in a giant machine but as individuals with specific needs.

For employers to curb staff turnover, strategies should be put in place to involve staff members in decision-making, which is at the core of good employee relations. To achieve 
better involvement, managers should consider introducing proactive structures for consulting with employees and their representatives. Gifford, Neathey and Lukas (2005) suggested that organisations introduce participation in decision-making focused on the following categories:

- general consultation committees (which discuss a range of business and other issues with employee representatives before management makes a final decision)

- joint working groups (usually focusing on a particular issue and where the employees involved could have considerable influence on outcomes)

- direct consultation (allowing individual employees to make their views known on particular issues typically achieved via face-to-face upward methods of communication between managers and employees or employee opinion surveys).

A spirit of continuous improvement needs to triumph (Townsend, Sundelowitz \& Stanz, 2007).

\section{Possible limitations of the study}

A possible limitation of this study is that the design is not suitable for the interpretation of results in a multivariate context. Kerlinger (1986) argued that multivariate methods are like the behavioural reality that they try to reflect: complex and difficult to understand and the most powerful. His argument rests basically on the idea that behavioural problems are almost all multivariate in nature and cannot be solved with a bivariate approach.

Turnover (intentions), with the many factors influencing this process, as also stated in this study, certainly falls in this category. One can probably also argue the inclusion of nonprofessional nurses in the sample. Although different risk groups are described, the sample does, to a certain extent, lack homogeneity.

It is also noted that the theoretical distinction among factors or determinants is sometimes conceptually confusing (e.g. in some studies, the concept of work environment refers to subdimensions that are different to those of others). It may also be a significant restriction to really understanding turnover behaviour when a sample is provided with a list of factors. One should keep in mind, due to the complex nature of understanding such behaviour, that the respondents are, in a sense, restricted.

\section{Recommendations for future research}

Although there is empirical evidence for some of the determinants in this study, research into understanding the turnover behaviour of nurses should receive much more attention. More theoretical models with the antecedents, manifestations and consequences of turnover to illuminate the concept should be developed.

Theoretically, there are two divergent types of generic turnover models: (1) micro-level models focusing on behavioural processes and outcomes and (2) macro-sociological models describing labour-market conditions and processes. The former emphasise the cognitive processes leading to a job search and the intention to leave, whereas the latter stress the structural factors linking turnover rates to the existence of and search for alternative external occupational opportunities. It is of the utmost importance to understand how the interaction between the macro and micro-level models affects nursing turnover. It is therefore strongly recommended that more emphasis be placed on multivariate designs to address this interaction.

Lastly, research should be extended to samples of nurses who have already left their employers to understand turnover behaviour and distinguish it from turnover intentions conceptually.

\section{Conclusion}

The objective of this study was to investigate voluntary turnover among nursing employees. It is clear from the research that this objective was met, as several determinants were identified that indicate to nursing employers which staff members are likely to terminate their employment. Nursing staff unanimously indicated that the most important reason that they would leave is related to unhappiness or discontent with their salary. It is therefore strongly suggested that employers investigate their current reward and recognition policies and practices to retain nursing staff. It is suggested that the hospital group should further investigate ways of making the work environment more conducive to creating rapport between management and nursing staff; more should be done within the workplace to create an environment where there is a spirit of co-operation and teamwork. This notion is supported by Jacobs (2005), in that employers can manage turnover by focusing on contextual factors.

\section{REFERENCES}

Anderson, R.A., Corazzini, K.N., \& McDaniel, R.R. (Jr.). (2004). Complexity science and the dynamics of climate and communication: Reducing nursing home turnover. Gerontologist, 44, 378-388.

Campion, M.A. (1991). Meaning and measures of turnover: Comparison of alternative measures and recommendations for research. Journal of Applied Psychology, 76(2), 199-212.

Cavanagh, S.J. (1990). Predictors of nursing staff turnover. Journal of Advanced Nursing, 15(3), 373-380.

Cavanagh, S.J., \& Coffin, D.A. (1992). Staff turnover among hospital nurses. Journal of Advanced Nursing, 17(11), 1369-1376.

Chiu, R.D., \& Francesco, A.M. (2003). Dispositional traits and turnover intention: Examining the mediating role of job satisfaction and affective commitment. International Journal of Manpower, 24(3), 284-298.

Currivan, D.B. (1999). The causal order of job satisfaction and organizational commitment in models of employee turnover. Human Resource Management Review, 9(4), 495-524.

Davidson, H., Folcarelli, P.H., Crawford, S., Duprat, L.J., \& Clifford, J.C. (1997). The effects of health-care reforms on job satisfaction and voluntary turnover among hospital-based nurses. Medical Care, 35(6), 634-645.

Gifford, J., Neathey, F., \& Lukas, G. (2005). Employee involvement: Information, consultation and discretion. IES Report 427, 2005, December.

Govender, S. (2002). Crisis looms over exodus of nurses. Retrieved June 25, 2004, from http://www.sundaytimes. co.za

Hargie, O., Tourish, D., \& Wilson, N. (2002). Communication audits and the effects of increased information: A followup study. The Journal of Business Communication, 39(4), $414-436$.

IRIN (2004). South Africa: A health system under pressure - Integrated regional information networks. Retrieved July 23, 2004, from http://www.irinnews.org/report.asp?

Irvine, D.M., \& Evans, M.G. (1995). Job satisfaction and turnover among nurses: Integrating research findings across studies. Nursing Research, 44(4), 246-253.

Iverson, R.D. (1999). An event history analysis of employee turnover: The case of hospital employees in Australia. Human Resource Management Review, 9(4), 397-418.

Jacobs, E.J. (2005). The development of a predictive model of turnover intentions of professional nurses. Doctoral dissertation. Johannesburg: University of Johannesburg.

Jacobs, E.J., \& Roodt, G. (2006). The development of a predictive model of turnover intentions of professional nurses. Proceedings of the Pan Pacific Conference XXIII, 29-31 May 2006, (pp. 70-72). Busan, Korea. 
Jacobs, E.J., \& Roodt, G. (2008). Organisational culture of hospitals to predict turnover intentions of nurses. Health $S A$ Gesondheid, 13(1), 63-75.

Kaplan, R.A., Boshoff, A.B., \& Kellerman, A.M. (1991). Job involvement and job satisfaction of South African nurses compared with other professions. Curationis, 14(1), 3-7.

Kerlinger, F.N.(1986). Foundations of behavioral research. (3rd.edn.). Fort Worth: Holt, Rinehart and Winston.

Lee, T.W., Mitchell, T., Wise, L., \& Fireman, S. (1996). An unfolding model of voluntary employee turnover. Academy of Management Journal, 39(1), 5-36.

Lee, H., Song, R., Cho, Y.S., Lee, G.Z., \& Daly, B. (2003). A comprehensive model for predicting burnout in Korean nurses. Journal of Advanced Nursing, 44(5), 534-545.

Leveck, M.L., \& Jones, C.B. (1996). The nursing practice environment, staff retention, and quality of care. Research in Nursing and Health, 19, 331-343.

Liebenberg, D. (2003, 17 September). Verpleërs moet so in SuidAfrika gehou word. [Nurses must be kept in South Africa]. Beeld, p. 5.

Lu, K.Y., Lin, P.L., Wu, C.W., Hsieh, Y.L., \& Chang, Y.Y. (2002). The relationship among turnover intentions, professional commitment, and job satisfaction of hospital nurses. Journal of Professional Nursing, 18(4), 214-219.

Lu, H., While, A.E., \& Barriball., K.L. (2004). Job satisfaction among nurses: A review of the literature. International Journal of Nursing Studies. Retrieved December 7, 2004, from http://www.sciencedirect.com

Mano-Negrin, R. (2001). An occupational preference model of turnover behaviour: The case of Israel's medical sector employees. Journal of Management in Medicine, 15(2), 106-124.

Mano-Negrin, R., \& Tzafrir, S.S. (2004). Job search modes and turnover. Career Development International, 9(5), 442-458.

McBey, K., \& Karakowsky, L. (2000). Examining sources of influence on employee turnover in the part-time work context. Leadership \& Organization Development Journal, 21(3), 136-144.

McCarthy, G., Tyrrell, M.P., \& Cronin, C. (2002). National study of turnover in nursing and midwifery, Department of Nursing Studies, University College Cork - National University of Ireland. Submitted to the Department of Health and Children for the Study of the Nursing and Midwifery Resource, report no. 1, July 2002.

Mobley, W.H. (1981). Employee turnover: Causes, consequences and control. London: Addison-Wesley Publishing Company.

Mobley, W.H., \& Griffeth, R.W. (1979). Review and conceptual analysis of the employee turnover process. Psychological Bulletin, 86, 493-522.

Mouton, J. (1996). Understanding social research. Pretoria: Van Schaik.

Newman, K., Maylor, U., \& Chansarkar, B. (2002). The nurse satisfaction, service quality and nurse retention chain: Implications for management of recruitment and retention. Journal of Management in Medicine, 16(4), 271-291.
Olivier, A. (2003, 2 July) SA kan oor 8 jaar 19000 verpleërs kort. [SA might need 19000 nurses within the next 8 years]. Beeld, p. 7.

Pela, M. (2003, 14 January). Brain gain hitting SA, says Mdladla. The Mercury, p. 1.

Phillips, N. (1990). Stress and stress management in nurse managers. Durban: University of Natal.

Price, J.L. (1977). The study of turnover. Ames: Iowa State University Press.

Price, J.L. (2001). Reflections on the determinants of voluntary turnover. International Journal of Manpower, 22(7), 600-624.

Razza, N.J. (1993). Determinations of direct-care staff turnover in group homes for individuals with mental retardation. Mental Retardation, 31(5), 284-291.

Rosin, H., \& Korabik, K. (1995). Organizational experiences and propensity to leave: A multivariate investigation of men and women managers. Journal of Vocational Behavior, 46, $1-16$.

Seo, Y., Ko, J., \& Price, J.L. (2004). The determinants of job satisfaction among hospital nurses: A model of estimation in Korea. International Journal of Nursing Studies, 41(4), 437-446.

Shezi, A. (2005). Nurses bitter at exclusion from Manuel's drive to better the lot of public servants. Business Day. Retrieved March 31, 2006, from http://www.homecomingrevolution. co.za/html

Shields, M.A., \& Ward, M. (2001). Improving nurse retention in the National Health Service in England: The impact of job satisfaction on intentions to quit. Journal of Health Economics, 20(5), 677-701.

Smetherham, J., \& Laurance, J. (2003, 13 May). UK poaching of SA nurses carries on despite ban. Cape Times, p. 5 .

Smit, M. (2003, 30 January). Die lampie brand al flouer. [The light is burning more dim]. Die Burger, p. 17.

Stolte, K., \& Myers, S.T. (1995). Reflections on recruitment and retention at the unit level. The Health Care Supervisor, 13(3), $36-45$.

Thom, A. (2003, 22 February). Where have all the nurses gone? Saturday Star, p. 13.

Townsend, M., Sundelowitz, E., \& Stanz K.J. (2007). 'Are they really satisfied?': An exploration of issues around Employee Satisfaction assessment strategies. SA Journal of Human Resource Management, 5(1), 28-34.

Van Niekerk, R., \& Sanders, D. (1997). South African Health Review 1997. Durban: Health Systems Trust and the Henry J. Kaiser Family Foundation.

Weisberg, J. (1994). Measuring workers' burnout and intention to leave. International Journal of Manpower, 15(1), $4-14$

Yin, J.T., \& Yang, K.A. (2002). Nursing turnover in Taiwan: A meta-analysis of related factors. International Journal of Nursing Studies, 39(6), 573-581.

Zeffane, R.M. (1994). Understanding employee turnover: The need for a contingency approach. International Journal of Manpower, 15(9/10), 22-37.

Zondagh, C. (2005). Impact of the global nursing shortage on quality patient care and nurses' quality of work life. Master's dissertation. Johannesburg: University of Johannesburg. 